\begin{tabular}{|c|c|c|c|}
\hline 垒田 誠 & 安藤 & 文英 & 横田 \\
\hline 浦 尚志 & 増本 & 陽秀 & 宮田 \\
\hline 俊逸 & 井林 & 博* & 岩本 \\
\hline
\end{tabular}

要 旨：早期に血管造影にて膀旁静脈に腫瘍塞栓を認め, 後に同部位に腫瘤形成をきたした混 合肝癌の一剖検例を報告する。症例は70歳女性で超音波検査で肝内に腫瘤形成を認め，血管造 影で肝左葉内側区に多数の腫瘍新生血管像, 両葉に数個の腫瘍濃染, 妏静脈 脐旁静脈の拡張 と同血管に腫瘍塞栓を認めた。16力月後, 右上腹部に腫瘤が出現し吸引細胞診にて肝細胞癌を 検出した. 計 4 回の TAE と抗癌剂投与を施行したが, 23カ月後に死亡. 剖検では肝の大部分を 胆管細胞癌が占拠し，左葉の一部に肝細胞癌が存在する混合肝癌であった。腹部腫瘤は門脈腫 瘍塞栓との連続性を欠く肝細胞癌の脐旁静脈への転移巣であり, 門脈王六進時に副側血行路の 一つである脐旁静脈に早期に厙瘍塞栓をきたし，ここに厙瘤を形成したものと診断した。

索引用語：脐旁静脈腫瘍塞栓混合肝癌腹壁腫瘤

はじめに

脐静脈一刘旁静脈は聞脈圧穴進時の全身静脈系への 副血行路のひとつである ${ }^{1,2)}$. 今回われわれは, 早期に 血管造影にて腫瘍塞栓を脐旁静脈に認め, 後に同部位 に董瘤を形成した混合肝癌の 1 例を経験したので，若 干の考察を加え報告する.

$$
\text { 症例 }
$$

患者: 70歳, 女性.

主訴：腹部腫瘤。腹部膨满感。

家族歴・生活歴・既往歴：特記事項なし。

現病歷：昭和56年初めて肝機能異常を指摘され, 肝 生検にて慢性肝炎の診断を受けた。昭和58年 AFP 值 の漸増傾向を示し，腹部超音波検査で肝両葉に数個の 低エコー域を検出された，腹腔動脈造影では肝左葉内 側区を中心に多数の腫瘍新生血管像之，払大した脐旁 静脈に腫湯塞栓を認め, 経動脈的腫第塞栓術（以下 $T E A)$ を施行. 以後さらに昭和 59 年 5 月と昭和 60 年 1 月に TAEを追加した。昭和 60 年 1 月より右上腹部に 蝩瘤を触知するようになり，昭和60年 5 月に当科へ第 5 回目の入院となった。

入院時現症：身長 $148 \mathrm{~cm}$, 体重 $57 \mathrm{~kg}$, 黄疸は認めな

“九州大学医学部第 3 内科

**同 第 1 病理学数室

〈受付日62年 2 月 6 日 $>$
いが貧血を認め，表在リンパ節は触知せず，右鎖骨中 線上に肝を 3 横指触知。表面は顆粒状で辺縁は鈍で硬 く压痛なく，脾を 2 横指さらに, 右上腹部に $3 \times 2 \mathrm{~cm}$ の 腫瘤を触知した，表面は平滑で弾性硬，压痛と呼吸性 移動を認めず，中等度の腹水を認めた。

検査成績 (Table 1)：末梢血に沉血球减少を認め，

Table 1 Laboratory data on admission.

\begin{tabular}{|c|c|c|c|}
\hline Blood & & CRP & $(+)$ \\
\hline WBC & $3200 / \mathrm{mm}^{3}$ & $\mathrm{HBs}-\mathrm{Ag}$ & $(-)$ \\
\hline $\mathrm{RBC}$ & $280 \times 10^{4} / \mathrm{mm}^{3}$ & HBs-Ab & $(+)$ \\
\hline $\mathrm{Hb}$ & $10.7 \mathrm{~g} / \mathrm{d} l$ & AFP 31 & $113.2 \mathrm{ng} / \mathrm{ml}$ \\
\hline PLTs $_{s}$ & $9.5 \times 10^{4} / \mathrm{mm}^{3}$ & CEA & $8.3 \mathrm{ng} / \mathrm{ml}$ \\
\hline T.P. & $6.5 \mathrm{~g} / \mathrm{d} l$ & \multicolumn{2}{|c|}{ Prothrombin time } \\
\hline Alb & $53.6 \%$ & & $13.9^{\prime \prime}\left(12.0^{\prime \prime}\right)$ \\
\hline$\gamma-g l$ & $27.6 \%$ & A-PTT & $36.5^{\prime \prime}\left(32.1^{\prime \prime}\right)$ \\
\hline GOT & $162 \mathrm{U} / \mathrm{L}$ & \multicolumn{2}{|c|}{ Hepaplastin test } \\
\hline GPT & $103 \mathrm{U} / \mathrm{L}$ & \multicolumn{2}{|c|}{$76.0 \%$} \\
\hline LDH & $309 \mathrm{U} / \mathrm{L}$ & ESR & $6 \mathrm{~mm} / \mathrm{hr}$ \\
\hline ALP & $162 \mathrm{U} / \mathrm{L}$ & \multicolumn{2}{|l|}{ Urine } \\
\hline$\gamma$-GTP & $93 \mathrm{U} / \mathrm{L}$ & \multicolumn{2}{|l|}{ Protein } \\
\hline $\mathrm{T}$. bil & $1.5 \mathrm{mg} / \mathrm{d} l$ & \multicolumn{2}{|c|}{ Sugar $\quad(-)$} \\
\hline D. bil & $0.6 \mathrm{mg} / \mathrm{d} l$ & \multicolumn{2}{|c|}{ urobilinogen $(-)$} \\
\hline T. chol & $199 \mathrm{mg} / \mathrm{d} l$ & \multicolumn{2}{|c|}{ occult blood $(-)$} \\
\hline $\mathrm{Ch}-\mathrm{E}$ & $153 \mathrm{IU} / \mathrm{L}$ & \multirow{2}{*}{\multicolumn{2}{|c|}{$\begin{array}{l}\text { Stool } \\
\text { occult blood }\end{array}$}} \\
\hline & & & \\
\hline & & ICG $R_{15}$ & $38.0 \%$ \\
\hline
\end{tabular}



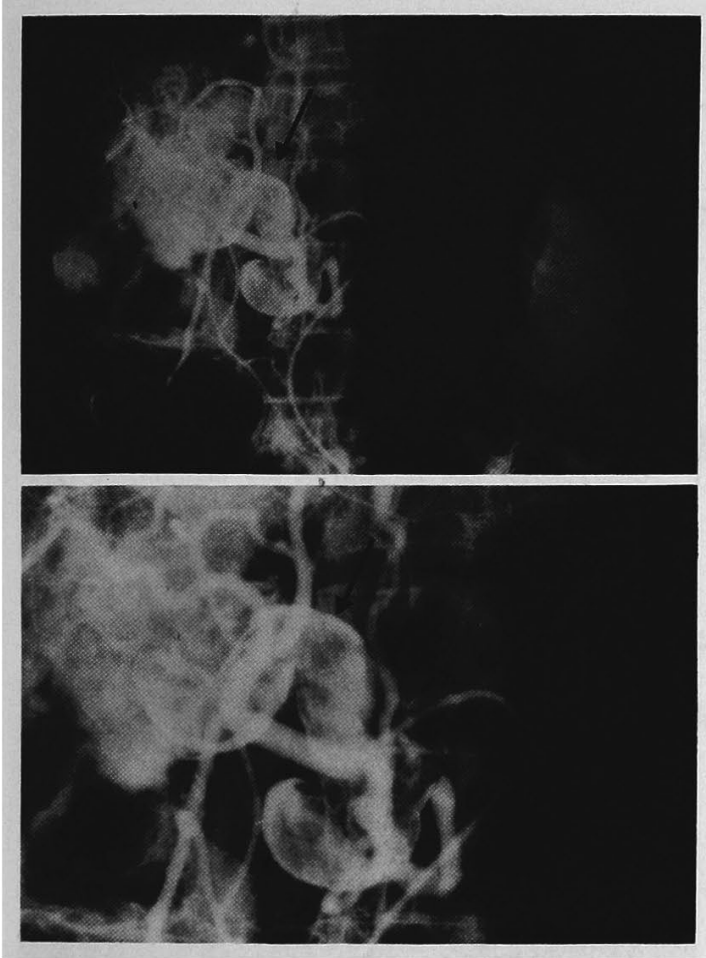

Fig. 1 Celiac angiography (arterial phase) demonstrated tumor neovascuralities in the region of middle hepatic artery, and hepatofugal flow via umbilical and paraumbilical vein with filling defect (tumor thrombus) $(\rightarrow)$. The lower picture is a magnification of the upper one.

軽度の低蛋白血症と， $\gamma$-グロブリン分画の上昇，扣よ びトランスフミナーゼと総ビリルビンの軽度の上㫒を 認めた。出血時間および凝固時間など凝固線溶系はは ぼ正常で, AFP とCEA の高値を認め, HBs 抗体陽性 であった. ICG 排泄試験（15分値）は低下（38\%）し， 肝硬変に合致する所見を呈した。

腹腔動脈造影：昭和58年 9 月の第 1 回目の腹腔動脈 造影は，動脈相 (Fig. 1) で中肝動脈支配領域に多数の 尰瘍新生血管像を認め, 両葉にも数個の腫瘍濃染を示 しまた肝門部付近より拡張，蛇行した脐静脈一脐旁 静脈像を認め, 脐旁静脈内部は filling defect を呈し腫 湯塞栓と診断した。静脈相では動静脈シャントにより 門脈が描出され，門脈左枝は腫㳹塞栓のために中枢側 が一部描出される所見をえ, 動脈相と同様に㑪静脈 一脐旁静脈像を示した。造影終了時には腫瘍塞栓の末 梢付近より上下方向に腹壁静脈を認めた。しかし昭和 59年以降の血管造影では脐静脈一脐旁静脈の描出を認

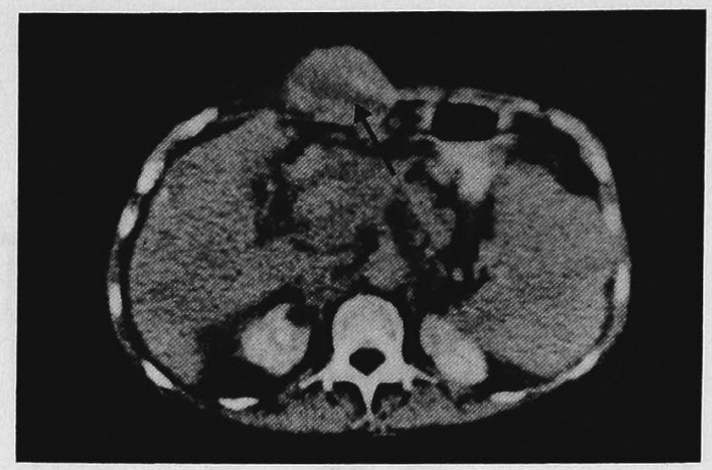

Fig. 2 CT $\operatorname{scan}$ (1985. 8) shows a massive tumor mass in abdominal wall $(\rightarrow)$.

めえなかった。

CT 像：昭和 58 年 10 月の CT は肝左葉内側区に低吸 収域と中等量の腹水を認めた，左前下方へ連続して不 鮮明な低吸収域が存在し，血管造影で認めた脐旁静脈 内の腫漡塞栓に一致する所見と判断した。昭和60年 8 月のCT (Fig. 2) では，腹壁内に皮廣表面に突出する 隆起性の腫瘤を認めたが，肝との明らかな連続性はな かった。

超音波検査：昭和60年 2 月の超音波検查で腹壁内腫 瘤は均一な低ェュー域を示し，肝との連続性はなくそ の中枢側に抎張した腣静脈一脐旁静脈を認めた。

穿刺細胞診：右上腹部遁瘤からの試料中に, 孤在性 ないし集合性の肝細胞様形態の細胞を認め，その核径 扣よび核胞体比の増大，核小体の明瞭化の所見から肝 細胞癌の転移巣と診断した。

臨床経過（Fig. 3)：計 4 回の TAE と化学療法にも かかわらず, 広範な他臓器への転移, 肝不全, 敗血症, 消化管出血のために昭和 60 年 8 月に死亡. 右上腹部腫 瘤に対しては昭和60年 6 月ピシバニール15KE, 7 月× タノールの腫瘤内注入を施行したが，畽瘤縮小なとの 効果なく，死亡時 $9 \times 7 \mathrm{~cm}$ まで堌大した。

剖検所見：肝は $1,100 \mathrm{~g}$, 白色調, 表面は顆粒状で, 右葉上部に手杽大の塊状型腫瘤と, その他両葉に多数 の小結節を，肝円索内に鶏卵大の腫瘤を認めた。組織 学的に肝は乙型肝硬変像で, 検索し得た範囲では肝内 腫瘤のほとんどは胆管細胞癌であった (Fig. 4).すな わち厚い線維組織中に円柱状で小核の細胞が不規則に 配列し, 散在性の管腔形成を示した、アルシャンブルー 陽性でムチンの産生を認めた。一方，訮右葉の手手大 の胆管細胞癌に接する左葉内側区に径約 $3 \mathrm{~cm}$ の結節 を認め, 同部は組織学的に肝細胞癌であった(Fig. 5). 


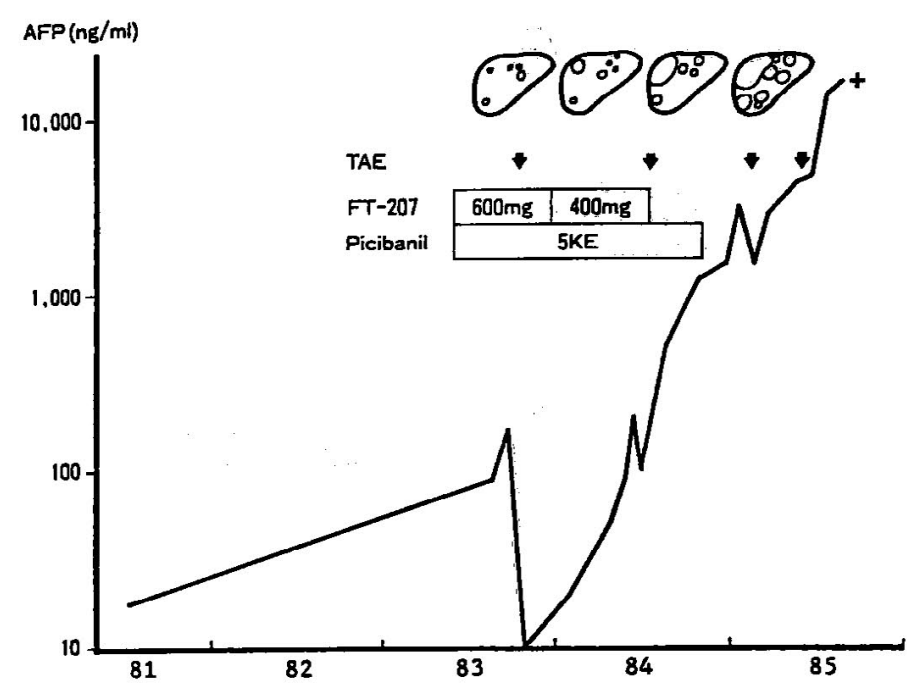

Fig. 3 Clinical course.

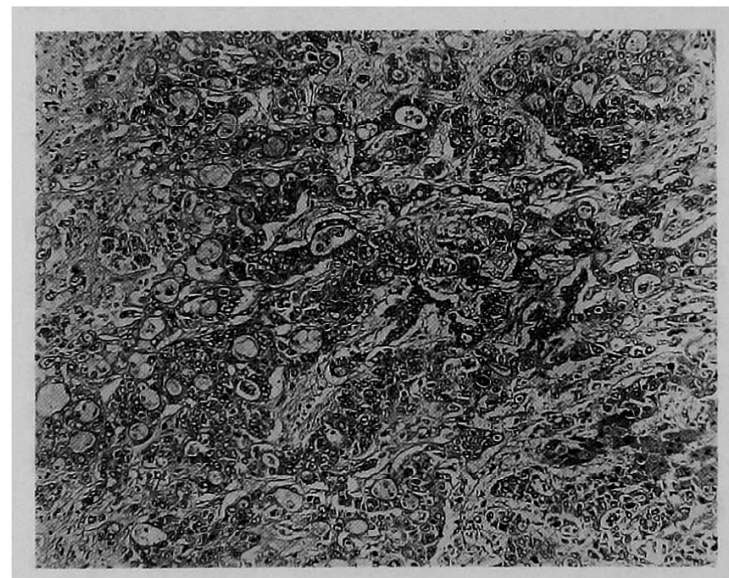

Fig. 4 Cholangiocellular carcinoma arranged in tubular formation with dense and fibrous stroma, and with mucous production ( $\mathrm{H} \& \mathrm{E}, \times 83)$.

好酸性の細胞が索状に配列しビリルビン産生を認め, Edmondson, Steiner 分類の Grade II であった. 肝円 索の断面では, 肝前緑より $5 \mathrm{~mm}$ の部分で膠様質の中心 に脐静脈を認め, 脐旁静脈には一部再蹯通化を示す基 質化された血栓形成を認めた（Fig. 6)，一方，肝前縁 より $10 \mathrm{~mm}$ の部分には肝細胞癌の蜂巣状増殖を認めた (Fig. 7，8）。遠隔転移としては肝細胞癌を肝円索と両 肺に，胆管細胞癌を両肺，膵，両鎖骨下リンパ節，縦 隔リンパ節, 胃・脺周囲リンパ節に認めた。肺では両 者は互いに分離して結節を形成し，一つの結節内に両 者の混在所見はなかった．免疫組織学的には転移巣る

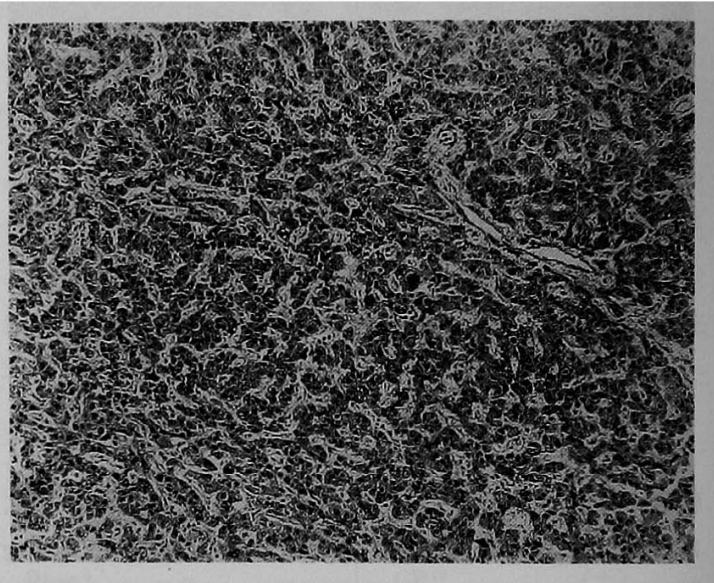

Fig. 5 Well-differentiated hepatocellulạr carcinoma growing in the trabecular pattern ( $H$ \& $\mathrm{E}, \times 83$ ).

含め, 肝細胞癌は PAP 法 AFP 染色弱陽性で, 胆管細 胞癌は CEA 染色に強陽性の所見をえた。

\section{考察}

本症例で注目すべき特徵的所見は，第 1 に肝細胞癌 が早期に脐旁静脈に腫瘍塞栓をおこし後に腫瘤形成港 至ったこと，第 2 に混合肝癌であったことである. 門 脈圧六進症におけける，全身静脈系への副血行路の $1 つ$ に脐静脈一脐堂静脈 ${ }^{1,2)}$ が注目され，Hoeuels ら $^{3)}$ は血 管造影法で, 肝硬変で食道静脈瘤非合併の門脈圧亢進 症11症例中 9 例 $(81.8 \%)$ ，脐静脈～脐旁静脈が副 血行路となっている所見を報告している，また，肝癌 


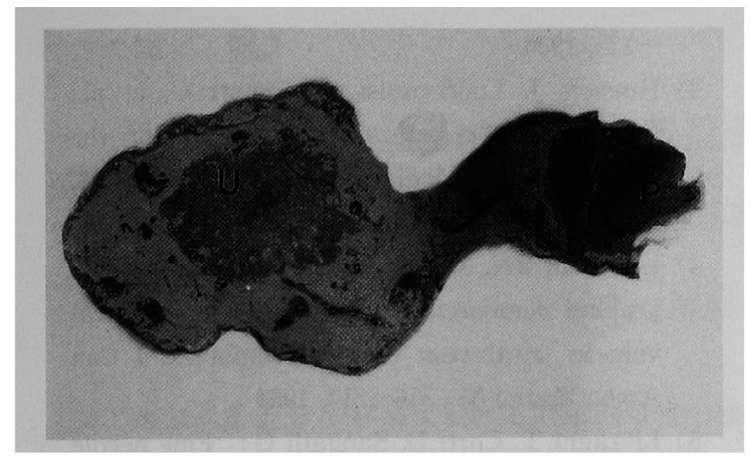

Fig. 6 Sagittal cut-surface of lig. teresa $(5 \mathrm{~mm}$ distant from the frontal margin of the liver). $\mathrm{U}$ : Umbilical vein, $P$ : paraumbilical vein with organized thrombus

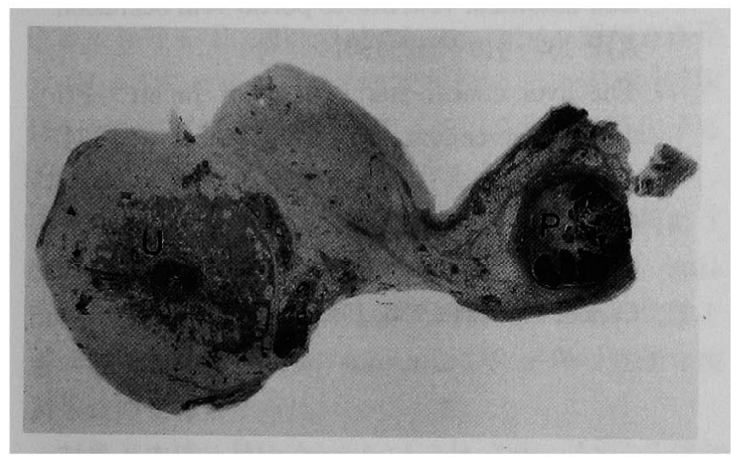

Fig. 7 Sagittal cut-surface of lig. teresa $(10 \mathrm{~mm}$ distant from the frontal margin of the liver). $U$ : Umbilical vein, $P$ : paraumbilical vein with tumor thrombus of HCC.

症例にお゙ける腫瘍の門脈浸潤はまれではないが, 㑪静 脈に腫湯塞栓を示す症例はわれわれが検索し得た範囲 では欧米文献で 3 例 ${ }^{4-6)}$ のみである. 全例とも超音波検 東により検出されており，同時に門脈圧え進に伴う膀 静脈の払大も認めている. 1 例では超音波下の fine needle biopsy が施行され5)，1例で剖検が行なわれて いる6).これらの症例では, 肝細胞癌が門脈左枝内の畽 瘍塞栓から㑪静脈へ連続性に直接浸潤を示したもので ある．本症例では門脈左枝に腫痬塞栓を認めたが，腫 場塞栓と脐旁静脈内転移巣との間には連続性を認めえ なかった. 從って副血行路としての脐静脈〜脐旁静脈 を介して，早期に門脈左枝の腫瑒塞栓から脐旁静脈に 血行性に転移したものと推定される。このように早期 に血管造影で脐旁静脈に腫瘍塞栓を認め, 後に腫瘤を 形成した症例は末報告と考える。

次に, 混合肝癌は肝細胞癌 (以下 HCC) と胆管細胞

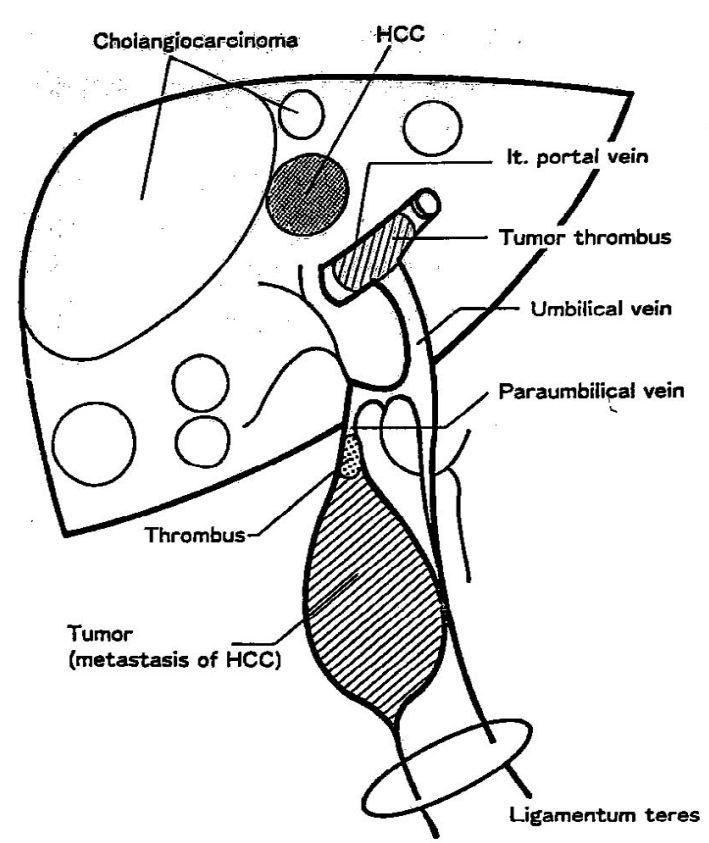

Fig. 8 Schema of the relationship between portal tumor thrombus and metastatic HCC in the paraumbilical vein.

癌（以下 CCC）の両者を含む原発性肝癌であり，本邦 では原発性肝癌の約 $1 \%$ 程度の稀な病態と指摘されて いる7). Goodman ら ${ }^{8)}$ は, 泥合肝癌を病理学的に 3 型に 分類し, I 型 (collision tumors) は HCC と CCC の偶 然的合併例，II型（transitional tumor）は HCC の特 徴である索状ないし pseudo-glandular な構造を示す 部分と, CCCに特徵的な腺腔形成やムチン産生を示す 部分とが混在する移行帯の存在例, III型（fibrolamellar tumors）は HCC 様の好酸性胞体を示す腫場細胞 が，同時にムチンを産生する CCC の性格をるち，若年 者に比較的多くかつ肝硬変を合併しないるのである。 本症例は肝左葉内側区の結節からの开 Edmondson II 型の HCC を認め，他は全て CCC で Goodman 分類の I 型に相当するるのと診断された。 さらに興味ある所 見として，免疫組織化学的に HCC 部はAFP 陽性であ り，CCC 部は CEA 陽性を示し，この点からも両者の 独立性が示された。

次に遠隔転移の検索では，本邦における集計では HCC は肺に, CCCはリンパ節に, 混合肝癌では肺と腹 膜に高率（各45.1\%，62.5\%，83.3\%，66.6\%）〕報 告されている. 本症例では HCC が肺と㑪旁静脈に, CCC が肺，膵とリンパ節に認められ，両要素が別個の 
転移パターンを示した，同一の臓器を原発巣としなが ら, 両者の転移対象葴器の相違は臨床的にも興味深い 所見である。

臨床経過については，本症例は TAEによく反応し て AFPは増減を繰り返した(Fig. 3)。剖検時の HCC は肝左葉に AFP 染色弱陽性の結節が 1 個のみであ $\eta$, 死亡直前の AFP 值か $10,000 \mathrm{ng} / \mathrm{m} l$ 以上の著增を みたことを考慮すると，その産生の大部分は遠隔転移 巣由来と考える. また CCC の部分は CEA 染色強陽性 で初回 TAE時よりCEA は軽度の上昇を呈しており， 血管造影と剖検所見を勘案すると, HCC とほぼ同時期 に発生したものと推察される。

$$
\text { 結語 }
$$

早期に血管造影にて脐旁静脈に尰煬塞栓を認め, 後 に同部位に腫瘤を形成した混合肝癌の一剖検例を報告

し, 若干の文献的考察を加えた。

$$
\text { 文献 }
$$

1) Lim G, Lunderquist A, Hagerstrand I: Umbilical and paraumbilical veins in ligamentum teres. Acta Radiologica $25: 1-5,1984$

2) Martin BF, Tudor RG: The umbilical and paraumbilical veins of man. J Anat 130: 305
$-322,1980$

3) Hoevels J, Lunderquist A, Simert G, et al : Portsystemic collaterals in cirrhosis of the liver. Acta Radiologica Diagnosis 20 : 865-877, 1979

4) Leekman RN, Matzinger M, Haber G: Sonographic demonstration of a patent umbilical vein in potal vein tumor thrombosis. $J$ Can Assoc Radiol 35 : 316-317, 1984

5) Livraghi $T$, Corti $D$, Sangalli $G$ : Fine needle biopsy of a patent umbilical vein thrombus demonstrates hepatocellular carcinoma. Diag Imaging $52: 322-324,1983$

6) Fakhry J, Gosink BB, leopold GR: Recanalized umbilical vein due to portal vein occlusion. AJR 137 : 410-412, 1981

7) The liver cancer study group of Japan: Primary liver cancer in Japan. Cancer 54: 1747 $-1755,1984$

8) Goodman $Z D$, Ishak KG, Langloss JM, et al : Combined hepatocellular-cholangio carcinoma. Cancer 55 : 124-135, 1985

\title{
An autopsy case of combined hepatocellular and cholangiocellular carcinoma with metastasis to paraumbilical vein
}

\author{
Makoto NaKamuTa, Bunei AndoH, Masaki Yokota, Akihide Masumoto, \\ Takashi MatsuURA, Yasuji Mryata, Shunichi Koga, \\ Hiroshi IBayash** and Taketo IWAMOTo**
}

In a case of 70-year-old female following chronic hepatitis for 5 years, high level of AFP was observed. By celiac angiography, many neovascuralizations were observed in the region of the middle hepatic artery and tumor thrombus formation in the enlarged paraumbilical vein. After 16 months from celiac angiography, a mass was seen in the right upper abdomen, and it was diagnosed hepatocellular carcinoma (HCC) by the needle biopsy specimen. She died of gastrointestinal bleeding after 23 months. An autopsy showed many nodules in the cirrhotic liver. One huge mass of metastatic HCC was found in the paraumbilical vein solitarily. Our findings indicates that this mass was formed with hematogenous metastasis from portal tumor thrombus of HCC through the enlarged umbilical and paraumbilical vein, one of portal systemic collaterals of portal hypertention. Interestingly, many nodules of cholangiocellular carcinoma were found in this cirrhotic liver in addition to HCC by histological examination.

* Third Department of Internal Medicine, Kyushu University (Fukuoka)

** First Department of Pathology, Kyushu University (Fukuoka) 